Article

\title{
Sustainability and the Expected Effects of Office-to-Residential Conversion in Historic Downtown Areas of South Korea
}

\author{
Eunkwang Kim ${ }^{1, *}$ and Sanghong Lee ${ }^{1,2, *}$ \\ 1 School of Architecture, Kyungpook National University, \#315, 2nd Engineering Building, 80, Daehak-ro, \\ Buk-gu, Daegu 41566, Korea \\ 2 Institute of Kyungpook National University Architecture \& Urban Space (IKAUS), \#1506, Global Plaza, 80, \\ Daehak-ro, Buk-gu, Daegu 41566, Korea \\ * Correspondence: eunkwang.kim@gmail.com (E.K.); Lsh@knu.ac.kr (S.L.); Tel.: +82-(0)-10-9960-3933 (E.K.); \\ $+82-(0)-53-950-5598$ (S.L.)
}

Received: 20 October 2020; Accepted: 16 November 2020; Published: 17 November 2020

check for updates

\begin{abstract}
South Korea has industrialized and urbanized rapidly since the 1970s, and subsequently, the historic downtown areas of major cities have been hollowed out as the population and industry have become concentrated in urban centers. Based on the Urban Decline Indicators of Korea, in accordance with the Urban Revitalization Act of the South Korean government, a comparative analysis of the population changes, office vacancy rate, building aging rate, decrease in the number of industries and employees, and housing supply and demand in historic downtown areas and new urban areas of six major South Korean cities demonstrated that all six historic downtown areas have declined significantly. Currently, little research is available in South Korea on the expansion of urban living and the inflow of urban residents through office-to-residential building conversion. Therefore, this study explores the expansion of urban residences to revitalize these historic downtown areas. To this end, this study examines the feasibility of converting poorly functioning, vacant offices in historic downtown areas into residential spaces to present a sustainable strategy for their complexation. This study finds that office-to-residential building conversion is a sustainable way to recover urban space and grow the population and industry in historic downtown areas.
\end{abstract}

Keywords: historic downtown decline; urban revitalization; urban housing; office vacancy rate; office-to-residential conversion

\section{Introduction}

Cities that have been built over hundreds or thousands of years are transforming, and historic business downtown areas are being abandoned in favor of new, purpose-built urban centers. The historic downtown areas are attractive spaces with historical and cultural preservation values, but they are declining because of the overall regional recession. Maintaining history and tradition, and at the same time the sustainable development of a compatible view of "preservation" and "development" is necessary for urban development that intends to preserve historic downtown areas. Sustainability in urban development, including urban population, economic, and social changes, must be achieved in a way that accommodates the needs of current and future generations while preserving the quality and ecological functions of the natural environment over time [1]. The importance of sustainability in urban revitalization is emphasized by urban problems stemming from the unprecedented increase in the population, which has resulted in economic growth, social welfare, greater demand for resources and energy, rising housing prices, a lack of jobs and land for development, and an overall poorer 
quality of life [2,3]. In other words, the urban environment plays an important role in addressing social and economic sustainability $[4,5]$.

In modern times, policies implemented to address the decline, collapse, or transformation of cities are referred to as "urban revitalization" policies. These are primarily aimed at solving the complex problems of modern cities by reactivating waning economic, social, environmental, and cultural functions [5-8]. Urban revitalization is necessary to solve economic problems, such as the decline of the urban economy and the decrease in the number of industries in a city, and social problems, such as population decline, population aging, and poverty. It can also solve spatial problems, such as piecemeal development and housing shortages [6,7]. Urban revitalization is being considered and implemented across a wide range of urban systems with sustainable development goals and long-term strategic objectives $[1,7,9]$. Rather than developing new urban infrastructure, urban revitalization projects seek to transform existing spaces that prevent the piecemeal development and expansion of cities, resulting in greater urban prosperity and a higher quality of life. Therefore, researching urban revitalization is the most effective means of studying methods for the comprehensive and sustainable improvement of urban problems [7]. The role of sustainable urban transformation policies is highlighted in the currently pursued urban revitalization literature [1].

\section{Urban Regeneration New Deal Project of South Korea}

Many cities around the world are currently pursuing various policies and projects for urban revitalization with diverse methods and characteristics [10]. South Korea's urbanization centered on economic growth from the 1970s to the present, and population aging has progressed rapidly in urban areas [11]. In the 1970s, 50\% of the population lived in cities, but now there is an urbanization rate of more than $92 \%$. Rapid urban expansion due to the development of industry has created the problem of a lack of housing in cities. To solve this problem, the Korean government continued to select urban expansion development methods focused on apartments and new town development. However, as the economy stagnated, alongside low birth rates and an aging population, urban hollowing out and urban decline have occurred. Additionally, downtown redevelopment through demolition has created another form of community collapse [10]. In response, the government recognized the need for urban management and enacted, in 2003, the National Land Planning and Utilization Act [12], to implement urban environment improvement projects in areas requiring restoration of urban functions such as the improvement of residential environments and expansion of infrastructure for underdeveloped areas [11].

Additionally, in 2013, the South Korean government enacted the Special Act on the Activation and Support of Urban Regeneration [13] to promote an urban revitalization complex for high-tech industries that can perform administrative, commercial, industrial, and cultural functions by restoring the urban centers whose utility has deteriorated [14]. In 2017, the government launched the Urban Regeneration New Deal Project, which focuses on the participation of various development entities and the restoration of local social and cultural sites [15]. The government plans to contribute 50 million over five years to urban revitalization projects, starting in 2017. Through this financial support, the government aspires to restore economic, social, physical, and environmental vitality by rebuilding decrepit residential areas and reviving the declining functions of urban areas. As presented in Table 1, the specific goals of the Urban Regeneration New Deal Project are as follows: "urban innovation", by which historic downtown areas are restructured as innovative hubs to improve residents' quality of life and restore urban vitality; "economic revival by urban revitalization" through job creation; and "restoration of community and community integration" to strengthen the capacity for urban revitalization with the participation of local residents [15]. The Korean Urban Regeneration New Deal Project needs to examine the urban redevelopment successes that have been widely implemented. Residents and local governments may choose to redevelop the demolition method in accordance with individual laws, or they may choose the regeneration method of the New Deal Project, which is 
supported by the initial support budget. The Urban Regeneration New Deal Project is a resident-led business method that selects customized projects that reflect the residents' opinions.

Table 1. Strategies of the Urban Regeneration New Deal Project.

\begin{tabular}{|c|c|c|}
\hline Policy Goal & 3 Strategies & 5 Major Projects \\
\hline \multirow{2}{*}{$\begin{array}{l}\text { Improving the quality of life } \\
\text { and restoring urban vitality }\end{array}$} & \multirow{2}{*}{ Urban space innovation } & $\begin{array}{l}\text { Improvement of residential } \\
\text { environments in old residential areas }\end{array}$ \\
\hline & & $\begin{array}{l}\text { Establishing historic downtown areas } \\
\text { as an innovation base }\end{array}$ \\
\hline Creating new jobs & $\begin{array}{l}\text { Urban regeneration } \\
\text { economy activation }\end{array}$ & $\begin{array}{c}\text { Activation of urban regeneration } \\
\text { economic organization/Inducing } \\
\text { private participation }\end{array}$ \\
\hline \multirow{2}{*}{$\begin{array}{l}\text { Community recovery } \\
\text { and social integration }\end{array}$} & \multirow[t]{2}{*}{ Residential and local initiatives } & $\begin{array}{l}\text { Construction for urban } \\
\text { regeneration governance }\end{array}$ \\
\hline & & Gentrification proactive responses \\
\hline
\end{tabular}

There are also different ways of doing business to overcome the limitations of existing urban redevelopment projects, such as rising real estate prices and gentrification. Instead of large-scale total demolition, the government is gradually pushing for housing improvements and small-scale housing maintenance projects and focusing on installing basic infrastructure that is closely related to residents' lives, such as village parking lots and community support facilities. In other words, the ultimate goal of the Urban Regeneration New Deal Project is to revitalize urban functions and restore urban competitiveness to comprehensively regenerate cities by improving the physical environment and enhancing the capacity of residents in response to urban decline. $[15,16]$ With this policy, South Korea's urban revitalization is taking a new turn.

\section{Historic Downtown Revitalization in Korea}

\subsection{Decline of Historic Downtown Areas}

The decline of historic downtown areas refers to a phenomenon in which the central city of a metropolitan area has grown faster than the surrounding cities and assumes the administrative, commercial, and cultural functions of the region. However, the subsequent development of suburbs and the expansion of central functions and housing to the suburbs and rural areas result in a significant urban center contraction [17]. The rise in popularity of suburban areas over urban areas then exacerbates urban problems and accelerates the hollowing out of downtown areas, leading in turn to a decrease in public and private investment in these urban centers $[17,18]$. Existing infrastructure, educational facilities, and housing in urban centers become more neglected, resulting in the stagnation of public investment and economic and social development, which is detrimental to the vitality and growth of downtown areas [17-19]. Between the 1970s and the 1980s, such urban decline occurred in 70\% of cities in developed countries, such as the United States, the United Kingdom, and Germany [17]. Throughout South Korea's rapid industrialization and urbanization, which began in the 1970s, many problems - such as housing shortages, land shortages, and increased traffic-have arisen in urban centers as the population and industry moved into these locations. A hollowing out of the downtown areas began in the 1980s [20], and the decline of historic downtown areas progressed in the 21st century due to rapid urban aging. During the same period, the South Korean government focused more on policies for developing large-scale housing complexes outside the older downtown areas and in new cities, rather than on creating fundamental solutions for issues that arose in the historic downtown areas, resulting in their accelerated deterioration and decline.

As a result of the South Korean government's actions, a socioeconomic gap between historic downtown areas and new developments in South Korea emerged, which undermined 
the competitiveness of cities and rendered long-term development difficult [18]. Although crowded with office workers during the day, a decrease in the number of downtown residents resulted in very different daytime and nighttime environments, often leading to crime and other security issues [11]. Therefore, it is necessary to discuss ways to address the hollowing out of downtown areas and the revitalization of urban centers. This discussion is an important factor in implementing sustainable urban development [21].

The revitalization of urban centers must be guided by the objective of promoting culture, tourism, recreation, and housing, as well as central commerce, business, and administration functions. These objectives will increase exchanges among different entities within urban areas, such as residents, businesses, and tourists [20]. It is also necessary to devise strategic policies to address issues such as low household income, high unemployment and poverty, population declines, high vacancy rates, and the low housing supply rates that characterize urban areas in South Korea [21].

There is a correlation between the decline of historic downtown areas and the outflow of urban populations to suburban and rural areas [20]. As South Korea underwent industrialization and urbanization, the populations of all six major cities (Seoul, Busan, Daegu, Incheon, Gwangju, and Daejeon) in South Korea soared, but the populations of the historic downtown districts of these cities markedly decreased [20]. These population decreases caused rapid urban contractions, resulting in demographic and economic problems associated with job reductions and social problems linked with the subsequent increase in urban poverty. Necessary upgrades to the existing urban ecosystem through sustainable development can transform the aging spaces to provide a higher quality of life. To this end, research must be conducted on the methods necessary for retaining residents, transforming urban centers that have become slums, and maintaining a structure that promotes sustainable urban housing.

\subsection{Historic Downtown Housing}

To revitalize declining downtown areas, it is necessary to expand urban housing to accommodate and propel the growth of the population [22,23]. Urban revitalization through sustainable housing can significantly affect sustainable urban development more broadly [24]. The presence of urban residents provides cities with an impetus for fostering physical and economic improvements, in turn bringing new investments and opportunities to cities [23]. Therefore, expanding urban housing is an essential component of public policy for urban development and has great potential to contribute to sustainable development $[22,25]$.

The expansion of urban housing encompasses not only the buildings and units where people live, but also the common spaces where social and economic activities occur. Expanding these common areas provides diversity and generates new energy in a residential district. Well-planned urban residential spaces can contribute to reduced crime in cities, support social integration, and improve the quality of life [23]. Therefore, the promotion of urban housing as an urban revitalization measure can ensure the ongoing sustainability of urban residential populations in the long term. Further, the promotion of work-residence proximity and consumption of goods and services within urban residential areas reinvigorates the city and contributes to revitalizing declining downtown areas [23,24].

Therefore, it is important to transform the simple model of an urban center, which favors commerce, culture, and administration, into one which is complex, diverse, and includes housing [18]. Increasing the number of people living in urban centers inspires diversity, thereby securing the degree and scale of residential retainment, and is the starting point for solving various urban problems stemming from the hollowing out of the downtown $[20,23]$. Therefore, it is necessary to secure the residential population in historic downtown areas to revitalize urban centers, and to this end, it is imperative to expand urban residential areas [20]. This study explores how to expand urban housing to revitalize and prevent the hollowing out of downtown areas. Although the expansion of urban housing in South Korea's historic downtown areas, which are complex and densely developed, has environmental and physical constraints, office-to-residential conversion through a proper reuse of aged and old buildings can be a method of expanding urban housing. Therefore, this study seeks to present 
sustainable strategies for the diversification of historic downtown districts and urban revitalization by examining the feasibility of the office-to-residential conversion of poorly functioning office vacancies in the historic downtown area.

\section{Methods}

\subsection{Urban Decline Indicators}

For the Urban Regeneration New Deal Project, the South Korean government selected the Urban Decline Indicators of Korea [26] under the Special Act on the Revitalization and Support of Urban Regeneration [13]. The purpose of this project is to promote sustainable urban revitalization policies based on the new urban ideology by addressing city-specific decline patterns based on five statutory indicators. These indicators measure population reduction, the decreasing number of industries, and the worsening of living conditions due to the increasing proportion of old buildings. Based on the Urban Decline Indicators of Korea [26], this study compared and analyzed (1) the rate of population change, (2) the proportion of aging buildings, and (3) the decrease in the number of industries and workers in historic downtown areas and the new town areas in major South Korean cities. In addition, this study seeks to further investigate (4) office vacancy rates and (5) the demand for, and supply of, residential housing in historic downtown areas to identify the differences of decline between the historic downtown areas and new town areas, as well as explore the necessity of, and potential for, expanding urban housing as a means of revitalizing historic downtown areas.

\subsection{Subject Area}

The scope of this study was classified according to the administrative range of six major cities in South Korea, namely Seoul, Busan, Daegu, Incheon, Gwangju, and Daejeon. Each of these cities has a population of more than one million. Excluded from this study was Ulsan, whose development was centered around large industrial complexes. The historic downtown districts and new urban areas were determined for each city. In major cities in South Korea, multiple "dongs" or "areas" comprise a "district," and multiple "districts" comprise a city. The office vacancy rate and the deterioration of aging buildings were classified by street and the dong where the offices are concentrated. The number of businesses, the number of employees, housing demand, and housing supply were defined by the district's administrative range in which the streets and dong are located. Table 2 and Figure 1 below present the areas classified as the historic downtown areas and new urban areas for each city.

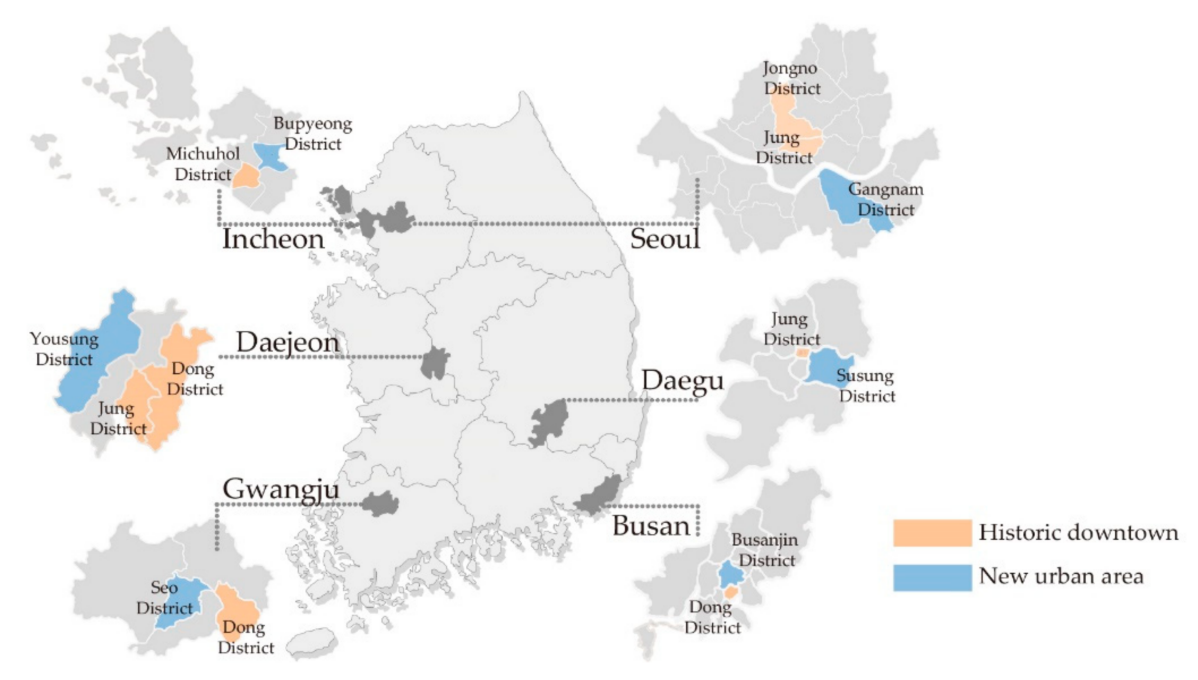

Figure 1. Research area map (Copyright: Authors). 
Table 2. Research area range of categories.

\begin{tabular}{|c|c|c|c|}
\hline & \multirow[b]{2}{*}{ Cities/Area } & \multicolumn{2}{|c|}{ Area Range of Categories } \\
\hline & & $\begin{array}{c}\text { Office Vacancy Rate, } \\
\text { Deterioration of Aging } \\
\text { Buildings }\end{array}$ & $\begin{array}{c}\text { Population, Housing } \\
\text { Supply/Demand, } \\
\text { Number of } \\
\text { Industries/Employees }\end{array}$ \\
\hline \multirow{2}{*}{ Seoul } & Historic downtowns & $\begin{array}{l}\text { Gwanghwamun Area, } \\
\text { Namdaemun Area, } \\
\text { Dongdaemun Area, } \\
\text { Myeong-dong, City } \\
\text { Hall Area, Eulji Area, } \\
\text { Chungmu-ro Area, }\end{array}$ & $\begin{array}{c}\text { Jongno District, Jung } \\
\text { District }\end{array}$ \\
\hline & New urban areas & $\begin{array}{c}\text { Gangnam-daero Area, } \\
\text { Nonhyeon Station Area, } \\
\text { Dosan-daero Area, Sinsa } \\
\text { Station Area, } \\
\text { Teheran-ro Area, } \\
\text { Seocho-dong }\end{array}$ & Gangnam District \\
\hline \multirow{2}{*}{ Busan } & Historic downtowns & Beomil-dong & Dong District \\
\hline & New urban areas & Seo-myeon Area & Busanjin District \\
\hline \multirow{2}{*}{ Daegu } & Historic downtowns & Dongseong-ro Area & Jung District \\
\hline & New urban areas & Suseong Area, Beomeo Area & Suseong District \\
\hline \multirow{2}{*}{ Incheon } & Historic downtowns & Juan Area & Michuhol District \\
\hline & New urban areas & Bupyeong Area & Bupyeong District \\
\hline \multirow{2}{*}{ Gwangju } & Historic downtowns & Geumnam-ro Area & Dong District \\
\hline & New urban areas & Sangmu Area & Seo District \\
\hline \multirow[t]{2}{*}{ Daejeon } & Historic downtowns & $\begin{array}{l}\text { Jung-dong, Eunhaeng-dong, } \\
\text { Daeheung-dong, } \\
\text { Sunhwa-dong }\end{array}$ & $\begin{array}{l}\text { Jung District, } \\
\text { Dong District }\end{array}$ \\
\hline & New urban areas & Dunsan-dong & Yousung District \\
\hline
\end{tabular}

Notes: Although Dunsan-dong is included in Seo District in Daejeon City, Seo District comprises Daejeon's historic downtown and new urban area. Geographically, Dunsan-dong is a new urban area that developed along with Yuseong District. Therefore, for housing supply rates and the analysis of the number of industries, Yuseong District was established as the range of the new urban area.

\section{Results}

\subsection{Population Change Rate}

According to the Urban Decline Indicators of Korea [26] denoted in the Special Act on the Revitalization and Support of Urban Regeneration [13], a significant decrease in population is defined as a decrease of more than $20 \%$ compared to the most populous period in the last 30 years, or a decrease in population in three or more consecutive years for the past five years in a given area. Table 3 presents the population change of all six major cities in South Korea and each historic downtown from 1980 to 2018. The total population of Seoul, Busan, Daegu, Incheon, Gwangju, and Daejeon increased between $7.5 \%$ and $170.9 \%$, but the population of each historic downtown decreased by $14.8 \%$ to $64.9 \%$. Based on the population decline indicator [26], all historic downtown areas are declining and require urban revitalization and support. The current decline in the populations of historic downtown areas may be a fundamental cause of, and an intensifying factor in, the hollowing out of the downtown area [20]. 
Table 3. Population Changes in the Urban Areas of Major Cities in South Korea (Source: KOSIS [27]).

\begin{tabular}{|c|c|c|c|c|c|c|c|}
\hline & & \multicolumn{5}{|c|}{ Population } & \multirow{2}{*}{$\begin{array}{c}\text { Percent } \\
\text { Change '00-'18 }\end{array}$} \\
\hline & & 1980 & 1990 & 2000 & 2010 & 2018 & \\
\hline \multirow{2}{*}{ Seoul } & Whole city & $8,364,379$ & $10,612,577$ & $9,895,217$ & $9,794,304$ & $9,673,936$ & $15.7 \%$ \\
\hline & Historic downtown & 535,067 & 431,449 & 305,291 & 276,719 & 287,764 & $-46.2 \%$ \\
\hline \multirow{2}{*}{ Busan } & Whole city & $3,159,766$ & $3,798,113$ & $3,662,884$ & $3,414,950$ & $3,395,278$ & $7.5 \%$ \\
\hline & Historic downtown & 217,585 & 184,350 & 122,087 & 93,976 & 84,557 & $-61.1 \%$ \\
\hline \multirow{2}{*}{ Daegu } & Whole city & $1,604,934$ & $2,229,040$ & $2,480,578$ & $2,446,418$ & $2,444,412$ & $52.3 \%$ \\
\hline & Historic downtown & 218,964 & 153,001 & 86,282 & 72,925 & 76,935 & $-64.9 \%$ \\
\hline \multirow{2}{*}{ Incheon } & Whole city & $1,083,906$ & $1,817,919$ & $2,475,139$ & $2,662,509$ & $2,936,117$ & $170.9 \%$ \\
\hline & Historic downtown & 487,025 & 457,883 & 409,945 & 416,088 & 415,102 & $-14.8 \%$ \\
\hline \multirow{2}{*}{ Gwangju } & Whole city & 727,600 & $1,139,003$ & $1,352,797$ & $1,475,745$ & $1,490,092$ & $104.8 \%$ \\
\hline & Historic downtown & 213,761 & 191,843 & 116,519 & 104,639 & 99,870 & $-53.3 \%$ \\
\hline \multirow{2}{*}{ Daejeon } & Whole city & 651,792 & $1,049,578$ & $1,368,207$ & $1,501,859$ & $1,511,214$ & $131.9 \%$ \\
\hline & Historic downtown & 651,792 & 596,374 & 501,371 & 502,401 & 476,581 & $-26.9 \%$ \\
\hline
\end{tabular}

\subsection{Aging Buildings}

The efficient use of buildings in urban centers is important for managing urban resources [28]. However, if a building fails to meet users' spatial requirements, or if the building is aging, decrepit, uses space inefficiently, lacks flexibility for space reformulation, and is of poor technical quality, its functionality can be considered inefficient [29]. Without major repairs, old office buildings are unsuitable for addressing the new demands of office workers [22]. Aging buildings are often left vacant because of their inability to compete with new constructions [30]. Therefore, repurposing the increasing number of aging buildings in urban centers may be an important solution for sustainable urban revitalization [28].

Under the Special Act on the Revitalization and Support of Urban Regeneration, buildings with deteriorating residential environments in areas where more than $50 \%$ of buildings are more than 20 years old are designated as urban revitalization sites [13]. Based on the Urban Decline Indicators of Korea, the ages of buildings in the historic downtown areas and new urban areas were compared. The percentages of buildings in historic downtown areas aged 20 years or older were 93\% in Seoul, 87\% in Busan, $89 \%$ in Daegu, 78\% in Incheon, 90\% in Gwangju, and 89\% in Daejeon. These percentages were lower in the new urban areas: $64 \%$ in Seoul, $83 \%$ in Busan, $75 \%$ in Daegu, $62 \%$ in Incheon, $6 \%$ in Gwangju, and 45\% in Daejeon (Figure 2).

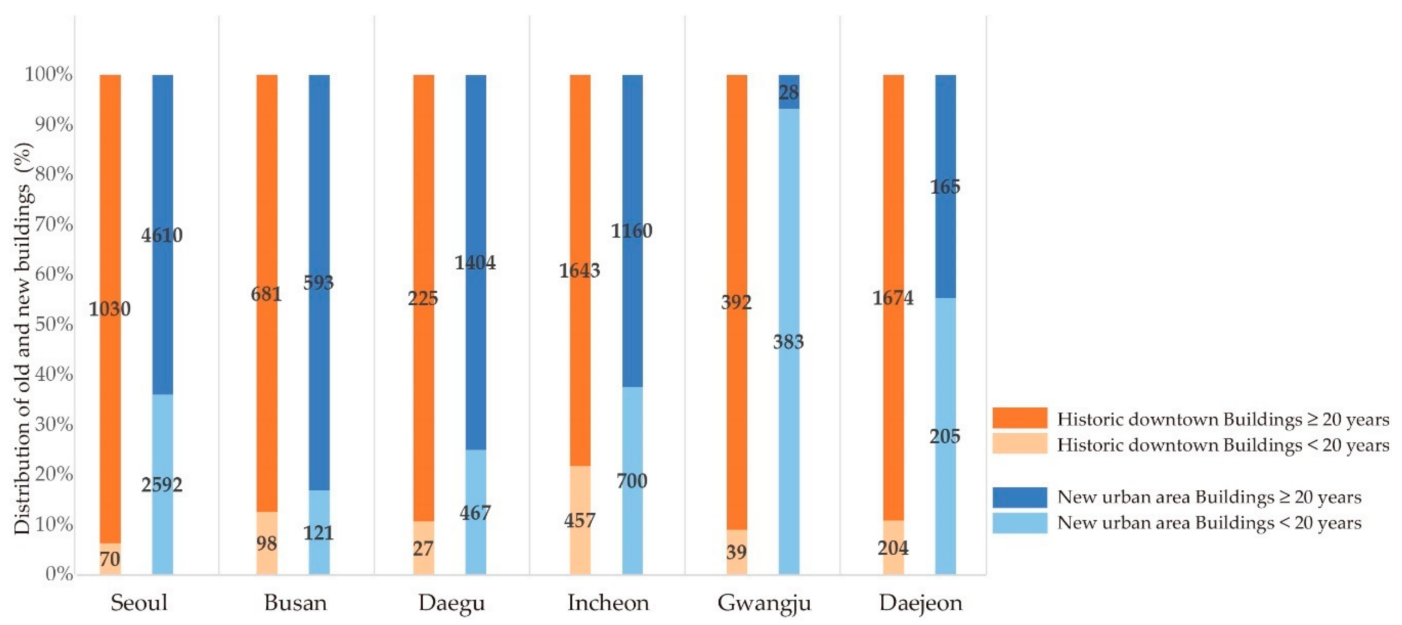

Figure 2. Old Building Stock Comparison for Major cities in South Korea (Source: KOSIS [31]). 
The age of buildings in the historic downtown areas of the six largest cities in South Korea is relatively higher than that of new town buildings, and the percentage of buildings aged 20 years or older is over $50 \%$ in all six urban centers. Therefore, compared to other regions under the Urban Decline Indicators of Korea [26], South Korea's six largest cities' historic downtown areas are in decline and require urban revitalization and support.

\subsection{Number of Industries and Employees}

Table 4 indicates the changes in the number of industries in the historic downtown areas and new urban areas in South Korea's six largest cities between 2000 and 2018. In Seoul, the number of industries in new urban areas increased by $35.2 \%$, from 39,095 to 52,853 , while in historic downtown areas, they decreased by $9.5 \%$, from 61,616 to 55,786 . Daegu also increased by $38.1 \%$, from 9411 to 13,001 , but the historic downtown area decreased by $9.2 \%$, from 10,837 to 9839 . The rate of change in the number of industries in the remaining four cities increased in both the historic downtown areas and the new urban areas, but the rate of increase in the number of industries in the historic downtown areas was lower than that of the new town areas. In particular, in Daejeon, the number of industries in the new urban areas conspicuously increased by $197.1 \%$, from 4565 to 13,563, while in the historic downtown areas, they increased by only $15.6 \%$, from 14,368 to 16,603 . Similarly, in Gwangju, the number of industries in new urban areas also increased by $99.4 \%$, from 7073 to 14,105 , but in the historic downtown areas, it increased by only $1.8 \%$, from 7815 to 7953 .

Table 4. Changes in the number of industries in major South Korean cities (Source: KOSIS [32]).

\begin{tabular}{|c|c|c|c|c|c|c|c|c|}
\hline & \multirow[b]{2}{*}{ City/Area } & \multicolumn{5}{|c|}{ Number of Industries } & \multirow{2}{*}{$\begin{array}{l}\text { Change } \\
\text { ‘00-'18 }\end{array}$} & \multirow{2}{*}{$\begin{array}{c}\text { Percent } \\
\text { Change } \\
‘ 00-18\end{array}$} \\
\hline & & 2000 & 2005 & 2010 & 2015 & 2018 & & \\
\hline \multirow{2}{*}{ Seoul } & Historic downtown & 61,616 & 57,126 & 49,293 & 58,780 & 55,786 & -5830 & $-9.5 \%$ \\
\hline & New urban area & 39,095 & 40,109 & 39,902 & 55,920 & 52,853 & 13,758 & $+35.2 \%$ \\
\hline \multirow{2}{*}{ Busan } & Historic downtown & 5793 & 5800 & 5919 & 6236 & 6152 & 359 & $+6.2 \%$ \\
\hline & New urban area & 15,164 & 13,730 & 12,691 & 14,953 & 16,113 & 949 & $+6.3 \%$ \\
\hline \multirow{2}{*}{ Daegu } & Historic downtown & 10,837 & 8164 & 7706 & 9352 & 9839 & -998 & $-9.2 \%$ \\
\hline & New urban area & 9411 & 10,218 & 11,107 & 12,480 & 13,001 & 3,590 & $+38.1 \%$ \\
\hline \multirow{2}{*}{ Incheon } & Historic downtown & 9801 & 9193 & 9455 & 11,043 & 11,834 & 2033 & $+20.7 \%$ \\
\hline & New urban area & 10,613 & 11,376 & 12,654 & 14,283 & 14,831 & 4218 & $+39.7 \%$ \\
\hline \multirow{2}{*}{ Gwangju } & Historic downtown & 7815 & 6535 & 5507 & 6657 & 7953 & 138 & $+1.8 \%$ \\
\hline & New urban area & 7073 & 9092 & 1019 & 13,142 & 14,105 & 7032 & $+99.4 \%$ \\
\hline \multirow{2}{*}{ Daejeon } & Historic downtown & 14,368 & 12,032 & 13,260 & 15,438 & 16,603 & 2235 & $+15.6 \%$ \\
\hline & New urban area & 4,565 & 5,919 & 8,385 & 11,945 & 13,563 & 8998 & $+197.1 \%$ \\
\hline
\end{tabular}

Table 5 indicates the change in the number of industrial employees in the historic downtown and new town areas of the six major cities in South Korea between 2000 and 2018. The number of employees in the industrial sector in Seoul increased by $40.7 \%$, from 474,914 to 668,441 , while in the historic downtown area, it increased by $15.2 \%$, from 484,000 to 557,638 , showing a significantly lower rate than the new urban areas. Gwangju's rate also increased by $160.5 \%$, from 49,047 to 78,721 , while the historic downtown rate decreased by $1.9 \%$, from 55,683 to 54,671 , which was a big difference in industrial employees. In Daejeon, the rate of change in industrial employees in the new town area and historic downtown areas was $200.0 \%$ and $42.1 \%$, respectively. Busan, Daegu, and Incheon also had a lower increase in industrial employees in the historic downtown area than in the new town area. As presented in Table 5, the rate of increase or decrease in the number of employees was very similar to that of the number of industries, and the rates of increase of employees in all six historic downtown areas were lower than those of the new urban areas [32]. This means that the increase or 
decrease in the number of industries directly affects the number of employees in the urban center. As a result, the decline in the number of industries leads to a decrease in the urban center population. South Korea's six largest cities' historic downtown areas have declined compared to new urban areas and require sustainable urban revitalization strategies.

Table 5. Changes in the number of employees in major South Korean cities (Source: KOSIS [32]).

\begin{tabular}{|c|c|c|c|c|c|c|c|c|}
\hline & \multirow[b]{2}{*}{ City/Area } & \multicolumn{5}{|c|}{ Number of Employees } & \multirow{2}{*}{$\begin{array}{l}\text { Change } \\
\text { ‘00-'18 }\end{array}$} & \multirow{2}{*}{$\begin{array}{l}\text { Percent } \\
\text { Change } \\
‘ 00-18\end{array}$} \\
\hline & & 2000 & 2005 & 2010 & 2015 & 2018 & & \\
\hline \multirow[b]{2}{*}{ Seoul } & Historic downtown & 484,000 & 471,072 & 521,049 & 586,452 & 557,638 & 73,638 & $+15.2 \%$ \\
\hline & New urban area & 474,914 & 517,296 & 612,544 & 679,288 & 668,441 & 193,527 & $+40.7 \%$ \\
\hline \multirow[b]{2}{*}{ Busan } & Historic downtown & 49,529 & 56,692 & 56,943 & 62,201 & 63,822 & 14,293 & $+28.9 \%$ \\
\hline & New urban area & 97,584 & 100,208 & 110,107 & 130,016 & 139,284 & 41,700 & $+42.7 \%$ \\
\hline \multirow[b]{2}{*}{ Daegu } & Historic downtown & 63,145 & 56,063 & 59,571 & 71,293 & 74,891 & 11,746 & $+18.6 \%$ \\
\hline & New urban area & 66,074 & 72,596 & 85,660 & 101,591 & 104,887 & 38,813 & $+58.7 \%$ \\
\hline \multirow[b]{2}{*}{ Incheon } & Historic downtown & 72,770 & 69,340 & 76,529 & 88,596 & 94,075 & 21,305 & $+29.3 \%$ \\
\hline & New urban area & 91,404 & 94,109 & 115,064 & 121,764 & 127,405 & 36,001 & $+39.4 \%$ \\
\hline \multirow[b]{2}{*}{ Gwangju } & Historic downtown & 55,683 & 48,716 & 45,961 & 49,024 & 54,617 & $-1,066$ & $-1.9 \%$ \\
\hline & New urban area & 49,047 & 70,219 & 95,468 & 111,742 & 127,768 & 78,721 & $+160.5 \%$ \\
\hline \multirow{2}{*}{ Daejeon } & Historic downtown & 95,118 & 86,193 & 107,213 & 123,235 & 135,139 & 40,021 & $+42.1 \%$ \\
\hline & New urban area & 45,411 & 57,419 & 87,536 & 120,688 & 136,227 & 90,816 & $+200.0 \%$ \\
\hline
\end{tabular}

\subsection{Office Vacancy}

Figure 3 illustrates the changes in the office vacancy rates in Seoul, Busan, Daegu, Incheon, Gwangju, and Daejeon and the national average from the first quarter of 2009 to the fourth quarter of 2018. The office vacancy rate in all cities and nationally increased from 2009 to 2018. In particular, the average office vacancy rate in Seoul increased from 4.9\% in 2009 to $12.1 \%$ in 2018, and Daegu also saw an increase in the vacancy rate, from $6.0 \%$ to $11.2 \%$. The national average increase in the office vacancy rate was smaller than that of Seoul, and it doubled from $6.6 \%$ in 2009 to $12.4 \%$ in 2018.

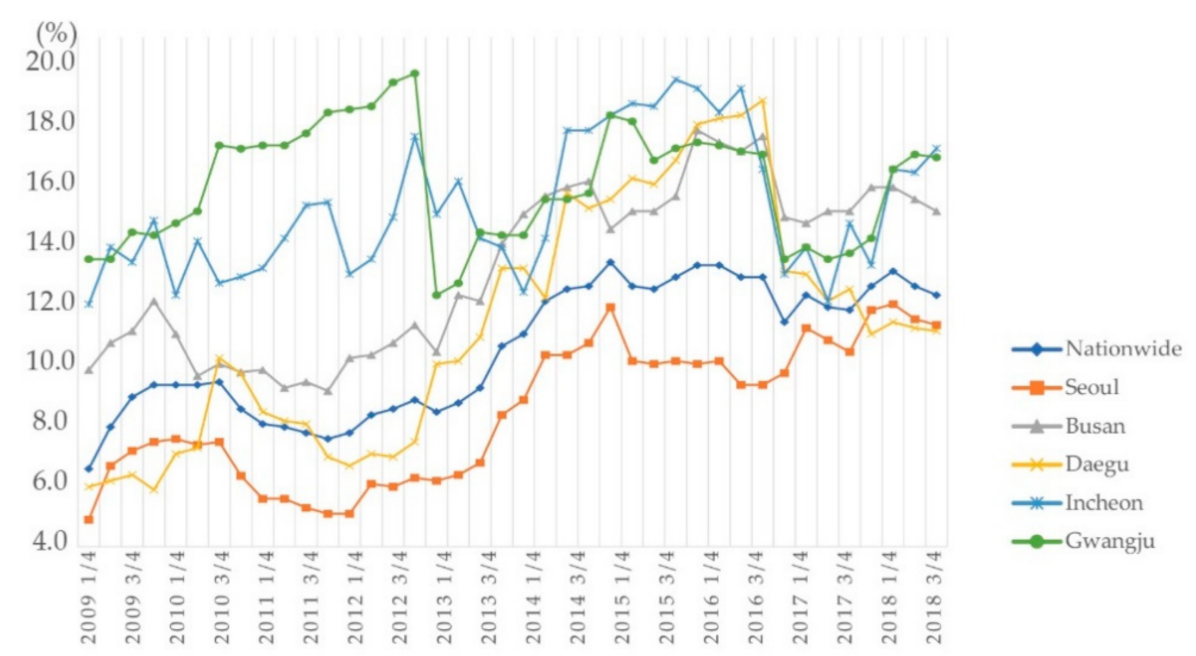

Figure 3. Office Vacancy Rates in South Korea (Source: KOSIS [33]).

Additionally, as presented in Figure 4, in the historic downtown areas in each of the six major cities, the office vacancy rates were higher in $2018(14.5 \%-33.4 \%)$ than the city averages $(11.2 \%-17.3 \%)$ and the new town area averages $(4.8 \%-14.4 \%)$. The office vacancy rates in the historic downtown areas were higher than those in the new urban areas by a minimum margin of $6.1 \%$ (Seoul) and a maximum 
margin of $27.9 \%$ (Gwangju). The vacancy rates of the historic downtown areas in Incheon $(16.8 \%)$ and Daejeon (16.4\%) were also higher than those of the new urban areas.

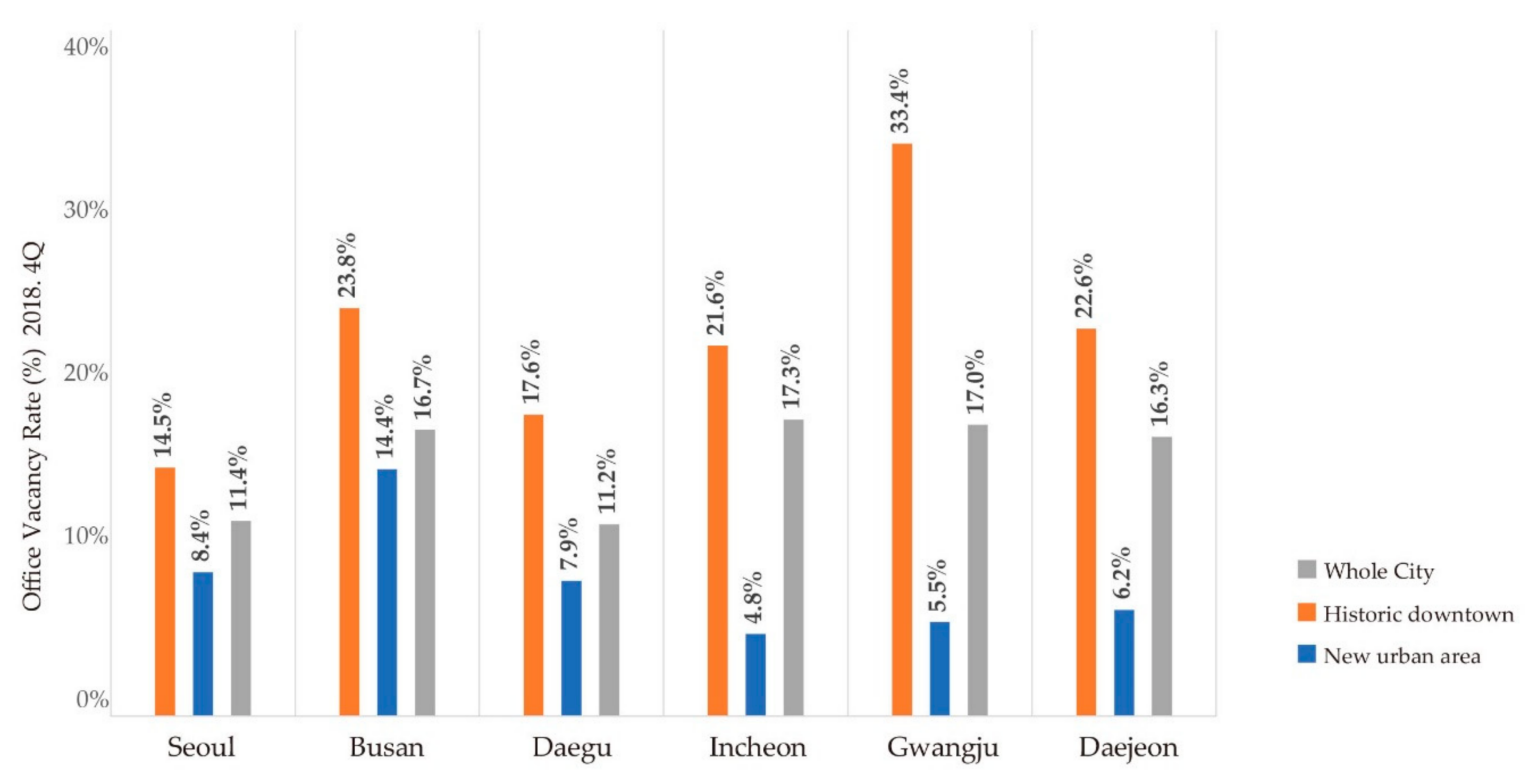

Figure 4. Office Vacancy Rate Comparison for Major cities in South Korea (Source: KOSIS [33]).

These results demonstrate that South Korea's six largest cities' vacancy rates have steadily risen for a decade, indicating a decline in historic downtown areas. An intra-city comparison of the office vacancy rates in historic downtown areas and new urban areas demonstrated high office vacancy rates in all six historic downtown areas. Therefore, based on the Urban Decline Indicators of Korea [26], the historic downtown areas of the six largest South Korean cities are in significant decline and require sustainable policies for urban revitalization.

\subsection{Urban Housing Demand}

As previously discussed, one way to revitalize urban centers is expanding the residential area, thereby promoting a population inflow into the city's residential retention [20,22-24]. Therefore, it is necessary to investigate the demand for urban housing before considering policies to promote its expansion.

Table 6 compares the average sales rates for newly built private apartments between 2018 and 2019 among six major cities and rural provinces in South Korea. The initial sales rates of new apartments in the major cities from the first quarter $(93.4 \%)$ of 2018 to the fourth quarter $(100 \%)$ of 2019 was higher than the national average $(91.7 \%)$ and the rural average $(76.2 \%)$. This indicates that urban housing demand is higher than the demand in rural areas. Thus, expanding urban housing may be a feasible way of increasing the population of urban centers.

The housing supply rate in South Korea exceeded $100 \%$ in 2018, indicating a statistically sufficient housing supply [35]. However, as presented in Figure 5, all historic downtown areas and new urban areas in the six largest cities had housing supply rates below the national average. Therefore, the housing supply in South Korea may be stable nationwide, but it is lacking in the urban centers of large cities where demand is strong. In particular, each historic downtown area has a smaller housing supply than the new urban areas. Compared to developed countries that recognize $110 \%$ as a stable housing supply rate, the housing supply rates in South Korea's historic downtown areas, at 77.0-89.6\%, are very low [20]. Overall, while the high private apartment sales rates, illustrated in Table 6, indicate high demand for housing in urban areas, the supply of housing in historic downtown areas falls short of such demand, indicating the necessity of new housing in urban areas. 
Table 6. Sales of Newly Built Apartments in South Korea (\%) (Source: KOSIS [34]).

\begin{tabular}{ccccccccc}
\hline & 2018 Q1 & 2018 Q2 & 2018 Q3 & 2018 Q4 & 2019 Q1 & 2019 Q2 & 2019 Q3 & 2019 Q4 \\
\hline Nationwide & 86.5 & 81.5 & 84.1 & 85.6 & 81.7 & 82.8 & 84.0 & 91.7 \\
Seoul & 100.0 & 99.7 & 99.6 & 100.0 & 97.4 & 91.3 & 99.6 & 99.6 \\
Busan & 89.8 & 68.8 & 59.7 & 95.5 & 71.6 & - & 82.8 & 100.0 \\
Daegu & 95.5 & 100.0 & 94.5 & 97.2 & 99.9 & 81.5 & 86.6 & 93.4 \\
Incheon & - & 65.9 & 95.3 & 100.0 & 95.1 & 88.8 & 99.3 & 99.7 \\
Gwangju & 99.6 & 82.2 & - & 99.1 & 99.9 & 100.0 & 100.0 & 94.4 \\
Daejeon & 100.0 & 100.0 & 100.0 & - & 94.5 & - & 100.0 & 100.0 \\
Rural Area & 76.6 & 64.8 & 58.6 & 61.4 & 61.9 & 68.6 & 58.6 & 76.2 \\
\hline
\end{tabular}

Notes: (-) indicates that there is no data from KOSIS.

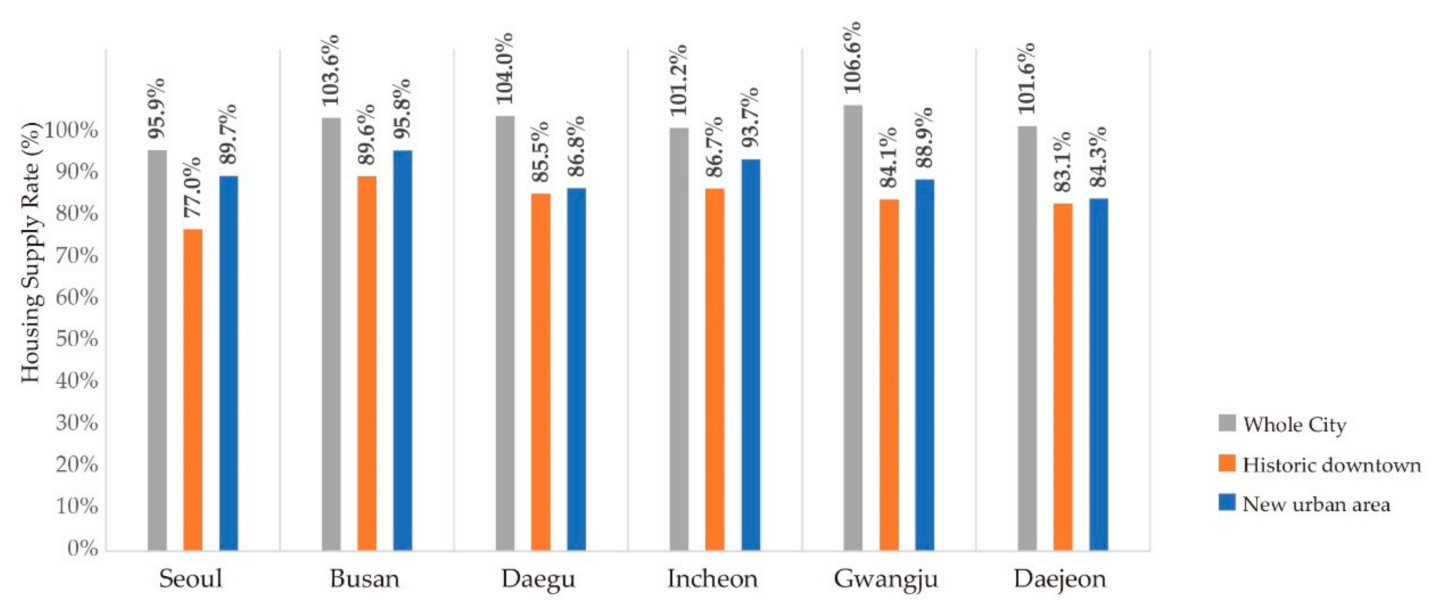

Figure 5. Housing Supply Rate in Major South Korean cities (Source: KOSIS [35]).

\section{Findings and Discussion}

To address the issues faced by historic downtown areas in South Korea, this study compared the degrees of decline between historic downtown areas and new urban areas in the six largest cities of South Korea based on urban decline indicators [13]. This analysis revealed that all of the historic downtown areas were significantly declining compared to new urban areas. Deteriorating living conditions caused by high office vacancy rates and the increased age of buildings have led to inefficient use of space in historic downtown areas, which directly impacts the economic decline of the city. In addition, problems such as population reduction, a decreasing or stagnant number of industries, and a low housing supply can decrease the number of settled residents and workers in historic downtown areas, which can further accelerate the hollowing out of the downtown area. This hollowing is accompanied by economic, social, physical, and environmental issues. Therefore, to implement effective urban revitalization methods, it is important to develop a simple model of historic downtown areas that promotes the administration, commerce, management, housing, and culture of the area to increase the resident population of the urban centers. Put simply, increasing the number of residents in historic downtown areas and improving land-use diversity serves as a strong starting point for resolving various issues associated with the hollowing out of the downtown area.

The ever-increasing office vacancy rate and the growing number of aging office buildings have caused spatial inefficiency in the historic downtown areas of South Korean cities. It is difficult to find land to build new residences in historic downtown areas, but it is easy to find buildings with high vacancy rates. This is because, over time, the potential value of urban land increases, while the value of the buildings decreases [36]. Long vacancies in office buildings in urban centers not only causes direct economic losses for building owners but may also present opportunities for social delinquency, such as property damage, trespassing, fires, and crime. In addition, buildings with high vacancy rates may 
negatively affect the reputations of surrounding areas and buildings, negatively affecting the whole city [29]. As one of the goals of sustainability is continuous improvement, the sustainable development and reuse of old buildings is one of the means to achieve this goal [37]. Jane Jacobs once argued that "Old ideas can sometimes use new buildings. New ideas must use old buildings" [38]. In other words, existing buildings should be appropriately recycled, and converting old and decrepit vacant office buildings into residential buildings presents innovative opportunities for urban revitalization [19,22,39]. Therefore, it is necessary to discuss whether the office-to-residential conversion is a realistic strategy for revitalizing declining historic downtown areas in South Korea and for the expansion of urban housing, and whether it is effective as a future-oriented urban revitalization policy.

\subsection{Sustainable Recovery of Urban Space}

Historic downtown areas in South Korea have a higher percentage of buildings aged 20 years or older than new urban areas (Figure 2). It is difficult to prevent the outflow of tenants from aging offices in South Korea's historic downtown areas without continued renovation by building owners or asset management companies or by reconstruction conducted by investment corporations. Factors that inhibit appeal to tenants include outmoded infrastructure; parking lots that cannot accommodate large vehicles; antiquated building systems; diminished interior space because of electricity, telecommunications, and additional air conditioning facilities; and antiquated service facilities such as elevators, toilets, public spaces, and small floor spaces. These factors may cause long-term or sustained increases in office vacancy rates, resulting in the decline of historic downtown areas. If aging buildings are not structurally defective and raise no functional problems in their ongoing use, office-to-residential conversions may be a sustainable means of urban revitalization. Repairing old office buildings that function poorly in terms of administration and commerce and transforming them to serve as residences may present opportunities for restoring declining downtown areas.

There is a high demand for housing in historic downtown districts in South Korea (Table 6), but supply falls short (Figure 5). It is difficult to expand urban housing through new constructions in South Korean cities due to high land prices and low housing supply rates, compared to suburban areas. Increasing the residential population of historic downtown areas through new constructions would also require a large land area in the urban center, where space is at a premium. Over their long history, South Korea's historic downtown areas have undergone large and small developments to create complex urban ecosystems, rendering it difficult to construct new, large-scale developments that are comparable to those in suburban areas. This presents marked difficulties in expanding urban residential space to increase the number of residents in the historic downtown areas. Therefore, it is necessary to examine whether it is appropriate to utilize vacant offices as urban residences to accommodate a larger population under the adverse conditions present in historic downtown areas.

As presented in Figures 3 and 4, the vacancy rates of historic downtown areas in South Korea are increasing, and the vacancy rates of all historic downtown areas are higher than those of the new urban areas. Due to the shortage of space for expanding urban housing and the vacancy of old offices, the historic downtown areas in South Korea are experiencing severe spatial inefficiencies. This increase in the office vacancy rate is expected to continue for the foreseeable future because of the continually rising consumer price index and the steadily low annual economic growth rate [40]. As a result, if office-to-residential conversions can revitalize poorly functioning office spaces, the efficiency of sustainable urban spatial use improves. Thus, it is necessary for historic downtown areas to sustainably reconfigure the wasted space in vacant offices to expand the urban housing supply.

The area of vacant offices available for conversion is estimated in Table 7. Historic downtown areas in South Korea have office vacancy rates ranging from $14.5 \%$ to $33.4 \%$ (Figure 4 ), and the area wasted may be estimated as the space excluding natural vacancies, as noted by Sivitanides [41]. Sivitanides defines natural vacancy as the optimal inventory, taking into account the marginal costs of tenant demand and vacancy retention; that is, the vacant stock facilitates the search process for tenants and lessors [41]. Sanderson presented estimates of global and regional natural vacancy rates 
of $5.6 \%$ in the Asia Pacific region, $6.7 \%$ in Europe, $11.6 \%$ in North America, and $8.1 \%$ globally [ 42 ]. The office area available for conversion to residential space may be estimated by subtracting the natural vacancy from the overall office vacancy rate, as illustrated in Table 7. This study assumes that South Korea's natural office vacancy rate is somewhere between $6 \%$ and $9 \%$, based on Sanderson's global and Asia Pacific estimates, as well as maximal changes over time. The estimated office area that can be converted into residential space in South Korea's historic downtown areas is a valuable urban asset for residential expansion (Table 7). Therefore, reconfiguring idle, decrepit, and vacant offices in historic downtown areas of South Korea is a way to create valuable community resources from unproductive assets while substantially reducing land acquisition and construction costs, preserving and securing existing facilities, and, ultimately, sustainably developing urban centers.

Table 7. Estimates of empty office area in historic downtown areas, 2018, Q4 (Source: KOSIS [43]).

\begin{tabular}{ccccc}
\hline Total Office Area & Vacancy Rate & $\begin{array}{c}\text { Assumed Value of } \\
\text { Natural Office } \\
\text { Vacancy Rate }\end{array}$ & $\begin{array}{c}\text { Estimated Empty Office } \\
\text { Area without Natural } \\
\text { Office Vacancy Rate }\end{array}$ \\
\hline Seoul & $3,822,359 \mathrm{~m}^{2}$ & $14.5 \%$ & $5.5-8.5 \%$ & $210,229-324,900 \mathrm{~m}^{2}$ \\
\hline Busan & $157,148 \mathrm{~m}^{2}$ & $23.8 \%$ & $14.8-17.8 \%$ & $23,257-27,972 \mathrm{~m}^{2}$ \\
\hline Daegu & $443,477 \mathrm{~m}^{2}$ & $17.6 \%$ & $8.6-11.6 \%$ & $38,139-51,443 \mathrm{~m}^{2}$ \\
\hline Incheon & $140,145 \mathrm{~m}^{2}$ & $21.6 \%$ & $12.6-15.6 \%$ & $17,658-21,862 \mathrm{~m}^{2}$ \\
\hline Gwangju & $486,504 \mathrm{~m}^{2}$ & $33.4 \%$ & $24.4-27.4 \%$ & $118,706-133,302 \mathrm{~m}^{2}$ \\
\hline Daejeon & $231,573 \mathrm{~m}^{2}$ & $22.6 \%$ & $13.6-16.6 \%$ & $31,493-38,441 \mathrm{~m}^{2}$ \\
\hline
\end{tabular}

\subsection{Sustainably Increasing Urban Population and Industries}

Although the total population of cities in South Korea has increased since the 1980s, the population of historic downtown areas has significantly decreased (Table 3), and the number of industries has decreased or increased at a rate significantly lower than in new urban areas (Table 4). Similarly, the number of industrial employees increased at a significantly lower rate or decreased (Table 5). The number of regionally-based industries that have long been established in historic downtown areas may decrease if local community links are undermined or diminished because of population declines. In particular, the continued development of administrative, commercial, and management-oriented industries in historic downtown areas may further accelerate a loss of diversity in the industrial composition of the communities.

Fewer residents and jobs in urban centers do not necessarily mean that the city is in decline. However, the decline of historic downtown areas may be related to the decrease in industrial diversity, the increasing rate of decline in the number of industries, and the decrease in employment and population [5]. Additionally, a lack of investment in declining downtown areas could encourage residents to move to the suburbs. A critical outflow and an eventual decline of the urban population would cause a decline in the urban economy $[5,17]$. Ultimately, population and economic decline result in reduced tax revenues and lower appeal for new industries and investment, further accelerating the decline of historic downtown areas [44].

However, if the residential population of South Korea's historic downtown areas increases through office-to-residential conversions, industries in various fields may flourish, thereby increasing the number of jobs available to workers and promoting the urban population's diversity. Such trends were seen in the Lower Manhattan Revitalization Plan (LMRP), in New York City, where more than sixty office buildings were converted to residential areas between 1995 and 2005. As a result, the number of residents in the area increased. In addition, the LMRP diversified the economic foundations of Lower Manhattan by promoting retail industries to supply services to local residents, reducing the region's heavy reliance on financial businesses [19]. Therefore, office-to-residential conversions must be considered to ensure the continued success of the Urban Regeneration New Deal Project pursued by 
the South Korean government and to understand its capacity to ensure a continual inflow of residents of various ages and income groups to the urban centers. For example, in urban areas where universities and private education facilities are concentrated, dormitory-type housing may be constructed for students. In contrast, the development of high-quality housing would draw higher-income earners to areas with favorable features, such as recreation and cultural facilities.

Where commercial and business facilities are concentrated, small-scale housing developments, such as single-person residences for office workers, may be required. Additionally, stable housing may be provided for young people in the form of public rental housing, and for young families, housing complexes with childcare and other community facilities could be developed. Older houses may be developed into hotel-style retirement homes for older residents in urban areas with a high population aging rate. The creation of urban residential facilities through multifunctional reprogramming, as presented in Figure 6, may allow a diverse range of people to settle in a city, contributing to an increase in the number of industrial entities and industrial diversity, which can serve as a powerful impetus for urban growth and a prerequisite for sustainable urban revitalization.

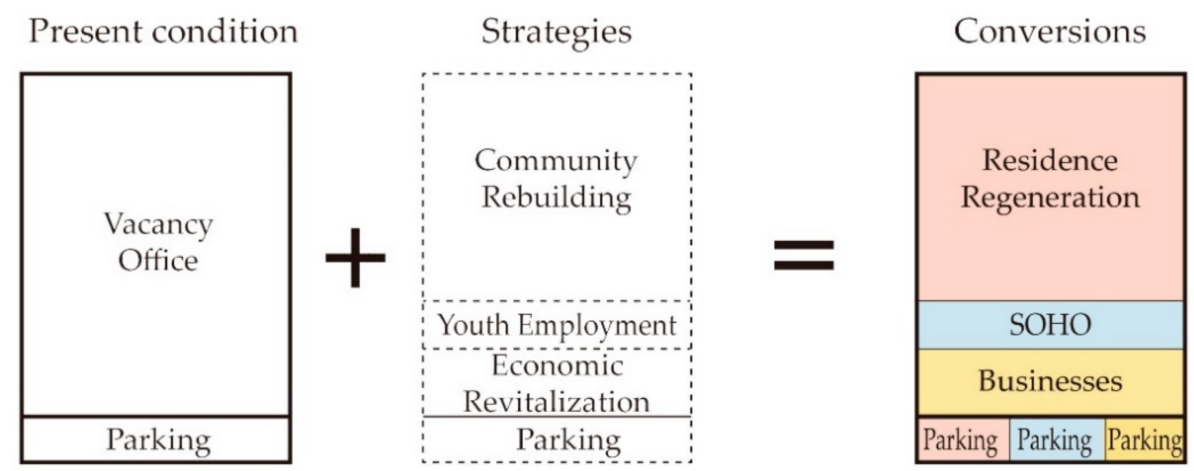

Figure 6. Reprogramming strategy for building regeneration (Copyright: Authors).

In addition to creating new residential spaces, converting the lower floors of office buildings to commercial spaces may allow such buildings to become central gathering points for communities. The development of low-rise commercial areas is closely related to the reinvigoration of streets, and the creation of active cultural and economic-oriented destinations contributes to successful urban revitalization. This, in turn, can lead to the economic revitalization of the urban center. The upper floors of low-rise commercial buildings may also be repurposed as flexible shared or startup offices with interiors that are easy to install, move, and dismantle, thereby preserving the existing office space's function and attracting young entrepreneurs to urban centers. Moreover, creating shared workspaces may promote employment by reducing commuting time, as they facilitate telecommuting or working from home and increase productivity by providing solutions for women with families to enter the workforce. Therefore, South Korea's historic downtown districts, whose current industrial structure is focused on administration, commerce, and management, have the potential to develop into urban centers with complex and diversified environments through office-to-residential conversions.

\section{Conclusions}

Historic downtown areas in South Korea are important locations with long-established histories and traditions. These areas have much potential and many attractions that represent each city's character from past to present. However, the era of rapid economic growth in South Korea has come to an end, and the hollowing out of the downtown areas that began in the 1980s undermines the cities' competitiveness, as diversity and vitality decline and infrastructure is underutilized. South Korea's historic downtown areas have lost their vitality due to the decline in population following a decrease in the number of industries and employees, as well as through the aging of their populations. To solve this diminishing vitality problem, the South Korean government has presented a clear vision for 
urban revitalization through its Urban Regeneration New Deal Project. Cooperative efforts between the central and local governments are now underway to restore the vitality of declining historic downtown areas.

This study assumes that increasing the number of residents in historic downtown areas is a priority for revitalization policies, and to this end, the urban housing supply must be expanded. An increase in housing in the historic downtown areas would provide advantages such as reinforcing the competitiveness of global cities by increasing the degree and scale of residential settlement, preventing such areas from deteriorating into slums, improving work-residence proximity, and facilitating the supply of production resources and workforce in urban areas. However, the historic downtown areas in South Korea, which have long alternated between development and decline, lack physical space to build new urban residences. Therefore, if currently poorly functioning surplus offices are converted into residential spaces, urban space may be used more efficiently, and sustainable urban revitalization can be achieved.

Furthermore, the expansion of urban residential infrastructure through office-to-residential conversion will revitalize historic downtown areas by generating a steady inflow of residents of diverse ages and incomes. To this end, it is important to develop downtown areas based on an analysis of their locational features and building functionality, as well as the connection between these two aspects. By investigating the location of a building, the value of the land it sits on, and the surrounding environment, buildings can be designed to accommodate the needs of their new residents appropriately. An increase in the number of urban residents through physical and spatial revitalization can promote an increase in the number of industrial entities and diversity in historic downtown areas, in turn ensuring the sustainability of urban revitalization. Therefore, the conversion of vacant office buildings to functional residential complexes may lead to higher future economic value and allow historic downtown areas to become more complex and diverse.

The resolution of housing problems and the hollowing out of downtown areas through an expansion of urban housing has already been implemented in many developed countries since the 1990s. Urban revitalization policies in these countries have included development methods for reconfiguring aging office buildings in downtown areas into residential and multipurpose buildings to enable work-residence proximity for residents and invigorate the cities through the facilitation of consumption within the urban living area. In the urban centers of large cities around the world, such as London, Manhattan, Chicago, Sydney, Vancouver, and Toronto, old buildings with high vacancy rates have been converted into residential units $[19,22,36]$. The recovery of old buildings in these cities has contributed to their reinvigoration and has promoted sustainable development and a high quality of urban life [22]. In contrast, the urban revitalization method of office-to-residential conversion is not widespread in South Korea. While there have been some cases in South Korea where downtown offices with high vacancy rates were repurposed as residences or hotels, most of these changes were made in accordance with the preferences of building owners or in anticipation of economic benefits, rather than as part of a conceptual approach to urban revitalization. A review of the direction of the Urban Regeneration New Deal Project pursued by the current government has demonstrated a necessity for further research on the conversion and expansion of old and vacant offices in declining historic downtown areas into urban residential facilities.

In the urban regeneration method introduced in the 1980s, South Korea has been promoting projects such as residential environmental improvements for old and deteriorated houses and urban environmental improvements for commercial and business function reorganization. Recently, some local governments, especially in large cities, have made plans for activities to improve the urban environment through the participation of residents in urban planning and urban design. However, many cities have not achieved the goals of urban regeneration within the enactment of laws, indicating the limitations of urban revitalization plans. This is because the first requirement is to create sustainable and active urban areas, rather than improving the aging of buildings and infrastructure, restoring the stagnant infrastructure industry, and improving the physical environment $[11,18]$. 
The declining residential population in urban areas has the greatest impact on urban decline. In other words, inducing the influx of the urban population through urban housing expansion will change the fundamental constitution of historic downtown areas and become a positive basis for establishing urban regeneration policies. To this end, it is necessary to diagnose the cause and background of urban growth and decline through "urban decline indicators [26]" to understand the necessity of urban regeneration. The population change rate in urban centers should be identified, and the analysis of the decrease in the number of industrial employees will provide the framework and direction for the basic design of the urban regeneration strategy. It is also necessary to set the spatial range of urban regeneration accurately, with indicators for old buildings, office vacancy rates, and urban housing demand in historic downtown areas, and suggest an evaluation index that meets urban regeneration goals.

This study compared and analyzed the historic downtown areas and new urban areas of the six major cities in South Korea through the Urban Decline Indicators of Korea [26] under the Special Act on the Revitalization and Support of Urban Regeneration [13]. The use of this city analysis index will also apply to cities in similar situations where urban decline is occurring after rapid urban development. As conversion is not a new phenomenon, but a solution applicable to old cities and buildings, the urban revitalization plan through the office-to-residential conversion can be universally applied and is an important method for urban regeneration worldwide. Unlike historic downtown areas in Europe, which have gradually developed over a long history, several developing countries such as China and Vietnam are currently undergoing an urbanization process focusing on rapid economic growth similar to that of South Korea in the 1970s, and will soon face problems of urban hollowing out and urban decline. Therefore, this study has great implications for South Korea and the majority of Asian countries that are engaged in rapid growth-oriented urban development. The method of expanding urban housing to increase the number of residents in the urban center through office-to-residential conversion is expected to become a new urban revitalization solution that can be adapted in many other countries.

Author Contributions: E.K. conceived, designed, analyzed, and wrote this paper. S.L. advised this research from the conceptual phase to writing. All authors have read and agreed to the published version of the manuscript.

Funding: This research was supported by the Basic Science Research Program through the National Research Foundation of Korea (NRF), funded by the Ministry of Education (2019R1F1A1059918).

Conflicts of Interest: The authors declare no conflict of interest.

\section{References}

1. Vojnovic, I. Urban sustainability: Research, politics, policy and practice. Cities 2014, 41, S30-S44. [CrossRef]

2. Toli, A.; Murtagh, N. Environmental Sustainability Indicators in Decision-Making Analysis on Urban Regeneration Projects: The Use of Sustainability Assessment Tools. In Proceedings of the ARCOM 2017 Conference, Cambridge, UK, 4-6 September 2017; Volume 33, p. 10.

3. Colantonio, A.; Dixon, T. Urban Regeneration and Social Sustainability: Best Practice from European Cities; Wiley-Blackwell: Chichester, UK, 2011; pp. 1-17.

4. Dawodu, A.; Akinwolemiwa, B.; Cheshmehzangi, A. A conceptual re-visualization of the adoption and utilization of the Pillars of Sustainability in the development of neighborhood sustainability assessment tools. Sustain. Cities Soc. 2017, 28, 398-410. [CrossRef]

5. Lang, T. Insights in the British Debate about Urban Decline and Urban Regeneration; Leibniz Institute for Research on Society and Space: Erkner, Germany, 2005; p. 25.

6. Priority Actions Programme. Guidelines for Urban Regeneration in the Mediterranean Region; Priority Actions Programme: Split, Croatia, 2004; Available online: https://www.pap-thecoastcentre.org/pdfs/Urban\% 20Regeneration.pdf (accessed on 24 June 2020).

7. Roberts, P. Evolution, Definition and Purpose of Urban Regeneration. In Urban Regeneration, 2nd ed.; Roberts, P., Granger, H., Sykes, R., Eds.; Sage: London, UK, 2017; pp. 9-44. 
8. Mateo, C.; Cuñat, A. Guide of strategies for urban regeneration: A design-support tool for the Spanish context. Ecol. Indic. 2016, 64, 194-202. [CrossRef]

9. La Rosa, D.; Riccardo, P.; Barbarossa, L.; Greca, P.L. Assessing spatial benefits of urban regeneration programs in a highly vulnerable urban context: A case study in Catania, Italy. Landsc. Urban Plan. 2017, 157, 180-192. [CrossRef]

10. Ball, M.; Maginn, P.J. Urban Change and Conflict: Evaluating the Role of Partnerships in Urban Regeneration in the UK. Hous. Stud. 2005, 20, 9-28. [CrossRef]

11. Kim, S.T. Analysis of the problems of donut phenomenon and measures to activate historic downtown. J. Resi. Environ. Inst. Korea 2007, 5, 223-243.

12. Law on Planning and Utilization of National Territory. Available online: http://www.law.go.kr/LSW/ lsSideInfoP.do?lsiSeq=51459\&joNo=\&joBrNo=\&docCls=\&urlMode=lsRvsDocInfoR\&chrClsCd=010201 (accessed on 24 March 2020).

13. Special Act on the Revitalization and Support of Urban Regeneration. Available online: http://www.law.go. $\mathrm{kr} / \mathrm{ls}$ InfoP.do?lsiSeq=149567\#0000 (accessed on 24 March 2020).

14. National Law Information Center. Enforcement Decree of the Special Act on Promotion of and Support for Urban Regeneration. Available online: http://www.law.go.kr/LSW/eng/engLsSc.do?menuId=2\&section= lawNm\&query=Urban+Regeneration \&x=0\&y=0\#liBgcolor0 (accessed on 29 June 2020).

15. Urban Regeneration Information System. What is the Urban Regeneration New Deal? Available online: https://www.city.go.kr/portal/policyInfo/newDeal/contents02/link.do (accessed on 28 June 2020).

16. Urban Regeneration New Deal. Korea Policy Briefing. Available online: https://www.korea.kr/special/ policyCurationView.do?newsId=148863980\#L1 (accessed on 28 June 2020).

17. Fol, S.; Cunningham-Sabot, E. Urban Decline and Shrinking Cities: A Critical Assessment of Approaches to Urban Shrinkage. Ann. Géogr. 2010, 674, 359-383. [CrossRef]

18. Lee, S.D. The Urban Rehabilitation Problem and the Expansion Strategy of Urban Housing Function. Plan. Policy 2004, 9, 36-45.

19. Beauregard, R. The Textures of Property Markets: Downtown Housing and Office Conversions in New York City. Urban Stud. 2005, 42, 2431-2445. [CrossRef]

20. Choi, H.I.; Yim, M.H. Housing Policy for the Prevention of Urban Hollowing-out. J. Korean Policy Stud. 2005, 12, 127-150.

21. Artibise, A. The Path to Sustainable Development in Metropolitan Regions: Federal and State Roles. In Revitalizing the City: Strategies to Contain Sprawl and Revive the Core, 1st ed.; Routledge: New York, NY, USA, 2005; pp. 410-416.

22. Heath, T. Adaptive re-use of offices for residential use: The Experiences of London and Toronto. Cities 2001, 18, 173-184. [CrossRef]

23. Roberts, P. Housing. In Urban Regeneration, 2nd ed.; Edgar, B., Taylor, J., Eds.; Sage: London, UK, 2017; pp. 153-170.

24. Winston, N. Urban Regeneration for Sustainable Development: The Role of Sustainable Housing? Eur. Plan. Stud. 2009, 17, 1781-1796. [CrossRef]

25. Priemus, H.; ten Heuvelhof, E. The long way to sustainable housing areas. Environ. Plan. B Urban Anal. City Sci. 2005, 32, 1-3. [CrossRef]

26. Urban Regeneration Information System. Urban Decline Indicators of Korea. Available online: https: //www.city.go.kr/portal/policyInfo/urban/contents01/link.do (accessed on 24 March 2020).

27. Korean Statistical Information Service. Population Census. Available online: http://kosis.kr/eng/statisticsList/ statisticsListIndex.do?menuId=M_01_01\&vwcd=MT_ETITLE\&parmTabId=M_01_01\&statId=1962001\& themaId=\#A_4.2 (accessed on 24 February 2020).

28. Schuurmans, A.; Dyrbøl, S.; Guay, F. Buildings in Urban Regeneration. IntechOpen 2018, 41-59. [CrossRef]

29. Remøy, H.; Van der Voordt, T. A new life: Conversion of vacant office buildings into housing. Facilities 2006, 25, 88-103. [CrossRef]

30. Remøy, H.; Van der Voordt, T. Adaptive reuse of office buildings: Opportunities and risks of conversion into housing. Build. Res. Inf. 2014, 42, 381-390. [CrossRef]

31. Building Life History Management System, Ministry of Land, Infrastructure and Transport. Available online: https://blcm.go.kr/cmm/main/mainPage.do (accessed on 24 March 2020). 
32. Korean Statistical Information Service (KOSIS). Number of Industries, Number of Employees by City, City, Industry, and Business. Available online: http://kosis.kr/statHtml/statHtml.do?orgId=101\&tblId=DT_ 1K52C01\&conn_path=I3 (accessed on 24 February 2020).

33. Korean Statistical Information Service (KOSIS). Office Vacancy Rate by Commercial District. Available online: http://kosis.kr/statHtml/statHtml.do?orgId=408\&tblId=DT_40801_N120201_01\&conn_path=I3 (accessed on 24 February 2020).

34. Korean Statistical Information Service (KOSIS). Average Initial Sales Rate of Apartments by Region. Available online: http://kosis.kr/statHtml/statHtml.do?orgId=414\&tblId=DT_41401N_008\&conn_path=I3 (accessed on 24 February 2020).

35. Korean Statistical Information Service (KOSIS). Housing Supply Rate. Available online: http://kosis.kr/ statHtml/statHtml.do?orgId=116\&tblId=DT_MLTM_2100\&conn_path=I2 (accessed on 24 February 2020).

36. Barlow, J.; Gann, D. Flexible Planning and Flexible Buildings: Reusing Redundant Office Space. J. Urban Aff. 1995, 17, 263-276. [CrossRef]

37. Bullen, P. Adaptive reuse and sustainability of commercial buildings. Facilities 2007, 25, 20-31. [CrossRef]

38. Jacobs, J. Death and Life of Great American Cities; Random House: New York, NY, USA, 1961; pp. 188-189.

39. Kim, E.K.; Lee, S.H. A Study on the Solution of the Offices Vacancy through Overseas Cases of Office-to-Mixed Use Conversion. J. Korean Hous. Assoc. 2019, 12, 93-102.

40. Ju, D.H.; Kim, J.J. A Study on the Factors Affecting the Vacancy Rate of the Office using VECM. J. Res. Environ. Inst. Korea 2016, 6, 93-108.

41. Sivitanides, P. The Rent Adjustment Process and the Structural Vacancy Rate in the Commercial Real Estate Market. J. Real Estate Res. 1997, 13, 195-209.

42. Sanderson, B.; Farrelly, K.; Thoday, C. Natural vacancy rates in global office markets. J. Prop. Invest. Finan. 2006, 24, 490-520. [CrossRef]

43. Korean Statistical Information Service (KOSIS). Basic Information of Offices by Business District. Available online: http://kosis.kr/statHtml/statHtml.do?orgId=408\&tblId=DT_40801_N1101\&conn_path=I3 (accessed on 24 February 2020).

44. Friedrichs, J. A Theory of Urban Decline: Economy, Demography and Political Elites. Urban Stud. 1993, 30, 907-917. [CrossRef]

Publisher's Note: MDPI stays neutral with regard to jurisdictional claims in published maps and institutional affiliations.

(C) 2020 by the authors. Licensee MDPI, Basel, Switzerland. This article is an open access article distributed under the terms and conditions of the Creative Commons Attribution (CC BY) license (http://creativecommons.org/licenses/by/4.0/). 